t. din. Fath (1949), 2,290.

THE DETERMINATION OF SERUM IRON WITH FERRICYANIDE

BY

\author{
JOSEPH FITZPATRICK AND KENNETH W. HOWELLS \\ From the Biochemical Department, Royal Infirmary, Glasgow
}

(RECEIVED FOR PUblication, APRIL 22, 1949)

There are numerous reagents which produce a coloured complex with iron and are, in general, suitable for the colorimetric determination of this substance. The minute amount of iron present in serum, however, restricts determinations to the iron thiocyanate or 0 -phenanthroline reactions.

In the thiocyanate method the colour fades rapidly and it is necessary to extract the coloured ferric thiocyanate complex with an organic solvent, in which many of the salts which inhibit the colour development and otherwise interfere are insoluble. The o-phenanthroline method is less sensitive than the thiocyanate method, but has the advantage that the colour developed is stable for long periods. The present work was undertaken to develop a method in which the colour was specific, stable, and intense enough to allow good readings to be obtained in the photoelectric colorimeter at the low level of iron concentration encountered in serum.

Ferrous iron forms a blue colour with potassium ferricyanide, and it was decided to utilize this colour for the iron determination. The nonhaemin iron is liberated from the serum by incubation with hydrochloric acid, the proteins precipitated with trichloracetic acid, and the iron in the protein-free solution reduced to the ferrous state with hydrazine sulphate, as described by Barkan and Walker (1940). Potassium ferricyanide is then added and the blue colour measured on the Spekker photoelectric absorptiometer.

\section{Experimental Work}

The coloured iron ferricyanide complex is soluble in excess of the reagent, and the present investigation shows that the colour can be used.for the quantitative determination of iron in serum. The blue colour, combined with the yellow of the excess ferricyanide, gives a green colour, the blue component of which is proportional to the iron concentration.

If potassium ferricyanide and hydrazine sulphate are left together in an acid solution, the solution after three or four hours assumes a greenish tinge which gradually increases in intensity. This colour, which is due to the decomposition of the ferricyanide, bears no relationship to the iron concentration of the test solution. In an actual iron estimation the colour due to the iron reaches a maximum in a quarter of an hour, is stable for a further two hours, and then begins to increase in intensity as described above.

Calcium, lead, and arsenic do not interfere with colour development at all. In the amounts normally present in serum, zinc and copper do not interfere, but when present in high concentrations, cause precipitation of their respective ferricyanide complexes. Oxalate completely inhibits colour development, and for this reason serum, and not plasma, was used throughout our experiments. Variation in the concentration of potassium ferricyanide used causes no change in the final? reading obtained, and practically no difference was found when the concentration used differed as much as from $5 \%$ to $20 \%$. Slight variation in the concentration of hydrazine sulphate causes no appreciable difference.

Provided the hydrochloric acid used to liberate the non-haemin iron does not exceed a concentration of $10 \%$ (volume/volume), the colour will not be affected, but should it rise above this, partial fading will take place, until at a concentration of $20 \%(\mathrm{v} / \mathrm{v})$ no colour develops at all. The final solution, therefore, must not be stronger than $0.2 \mathrm{~N}$ in respect of hydrochloric acid. Similarly, the amount of trichloracetic acid used to precipitate the proteins must not exceed the $2 \cdot \mathrm{ml}$. of $20 \%$. (weight/volume) otherwise fading will take place. Under the conditions described in our method, there is no interference from the hydrochloric acid or the trichloracetic acid. Sulphuric acid does affect the colour, but only when the solution is greater than $0.1 \mathrm{~N}$ in respect of sulphuric acid. Phosphate, sulphate, and chloride do not interfere.

\section{Method}

The following is a detailed description of pur method. 
Reagents.-The following reagents are used :

1. Hydrochloric acid, $5 \%(\mathrm{v} / \mathrm{v})$.

2. Trichloracetic acid, $20 \%(w / v)$.

3. Hydrazine sulphate, $1 \%(w / v)$, freshly prepared before use.

4. Potassium ferricyanide, $10 \%(w / v)$.

Double-distilled water is used in making up all - solutions, which are stored in acid-washed bottles. All other glassware used is also acid-washed, and then washed acid-free with double distilled water.

Procedure.-To $4 \mathrm{ml}$. serum in a thick walled test tube $2 \mathrm{ml}$. $5 \%$ hydrochloric acid is added and incubated at $37^{\circ} \mathrm{C}$. for one hour. This is cooled to room temperature and $2 \mathrm{ml} .20 \%$ trichloracetic acid added. It is then mixed, allowed to stand for at least one hour, and centrifuged for 15 minutes at 2,500 revolutions per minute. It is important that the mixture be allowed to stand for at least one hour, otherwise a clear supernatant fluid will not be obtained. If possible it should be left overnight before centrifuging.

To another test tube $4 \mathrm{ml}$. of the supernatant fluid are transferred. A blank is prepared in a third test tube by taking $2 \mathrm{ml}$. water, $1 \mathrm{ml}$. $5 \%$ hydrochloric acid, and $1 \mathrm{ml} .20 \%$ trichloracetic acid. To both $1 \mathrm{ml}$. $1 \%$ hydrazine sulphate is added, shaken, and left for five minutes. To each is added $1 \mathrm{ml}$. $10 \%$ potassium ferricyanide and $4 \mathrm{ml}$. water. The test tubes were left to stand for 15 minutes to allow the colour to develop. The colour is then measured in the Spekker photoelectric absorptiometer, using $1 \mathrm{~cm}$. cell and the Spekker red filter OR2. (We have found it convenient to set the Spekker drum at $\mathbf{0 . 2 0 0}$ using the blank in the solvent cell. The instrument is then adjusted until there is no deflexion in the galvanometer, and is ready for taking a series of readings. The unknown solution is placed in the other cell, and the drum rotated until there is no deflexion. The reading will be less than 0.200 . It has been found that this method saves considerable time when there are a number of estimations.)

To draw up a reference curve for the Spekker absorptiometer, we took tubes containing $0,2.5,5.0$, $7.5,10.0 \mu \mathrm{g}$. iron in $4 \mathrm{ml}$. water, added $1 \mathrm{ml}$. $1 \%$ hydrazine sulphate, $1 \mathrm{ml} .10 \%$ potassium ferricyanide, and $4 \mathrm{ml}$. water. The reference curve is read in the Spekker absorptiometer after 15 minutes.

\section{Results}

Recoveries of inorganic iron added to serum were shown to be quantitative, and from the figures shown on Table I will be seen to compare favourably with those obtained by existing methods.

A number of iron determinations were carried out on serum from patients with different clinical conditions, and the results are shown to lie between the usual limits of 100 and $200 \mu \mathrm{g}$. per $100 \mathrm{ml}$. (Table II).
TABLE I

ReCOVERY OF INORGANIC Iron ADDED to SERUM

\begin{tabular}{c|c|c|c|c|c}
\hline No. & $\begin{array}{c}\text { Initial } \\
\text { Iron } \\
\text { Content } \\
(\mu \mathrm{g} . \mathrm{Fe})\end{array}$ & $\begin{array}{c}\text { Iron } \\
\text { Added } \\
(\mu \mathrm{g} . \mathrm{Fe})\end{array}$ & $\begin{array}{c}\text { Total } \\
\text { Iron } \\
\text { Deter- } \\
\text { mination } \\
(\mu \mathrm{g} . \text { Fe) }\end{array}$ & $\begin{array}{c}\text { Iron } \\
\text { Recovered } \\
(\mu \mathrm{gg} . \mathrm{Fe})\end{array}$ & $\begin{array}{c}\text { Recov- } \\
\text { ery } \\
(\%)\end{array}$ \\
\hline 1 & 1.22 & 2.50 & 3.75 & 2.53 & 101.2 \\
2 & 1.50 & 4.00 & 5.35 & 3.85 & 96.25 \\
3 & 1.65 & 2.50 & 4.14 & 2.49 & 99.6 \\
4 & 1.83 & 2.50 & 4.23 & 2.40 & 96.0 \\
5 & 2.10 & 5.00 & 6.90 & 4.80 & 96.0 \\
6 & 1.79 & 2.50 & 4.30 & 2.52 & 100.4 \\
7 & 1.74 & 5.00 & 6.48 & 4.74 & 94.8 \\
8 & 1.12 & 2.50 & 3.53 & 2.41 & 96.4 \\
9 & 2.80 & 5.00 & 7.50 & 4.70 & 94.0 \\
\hline
\end{tabular}

TABLE II

The Iron Content of Human Serum

\begin{tabular}{c|l|c}
\hline No. & Clinical Condition & $\begin{array}{c}\text { Serum Iron } \\
(\mu g . \text { Fe/100 ml. })\end{array}$ \\
\hline 1 & Infective hepatitis & 140 \\
2 & Epistaxis & 90 \\
3 & Sciatica & 125 \\
4 & Tabes dorsalis & 175 \\
5 & Obstructive jaundice & 85 \\
6 & Hepatic cirrhosis & 115 \\
7 & Hepatitis & 165 \\
8 & Duodenal ulcer & 170 \\
9 & Splenic anaemia & 80 \\
10 & Pernicious anaemia & 125 \\
11 & Pernicious anaemia & 430 \\
12 & Pernicious anaemia & 430 \\
13 & Haemolytic anaemia & 115 \\
14 & Lead poisoning & 225 \\
15 & Lead poisoning & 160 \\
16 & Lead poisoning & 145 \\
17 & Lead poisoning & 190 \\
18 & Lead poisoning & 190 \\
19 & Lead poisoning & 125 \\
20 & Lead poisoning & 240 \\
21 & Lead poisoning & 205 \\
& & \\
\hline
\end{tabular}

\section{Summary}

A method for the determination of serum iron is described. The advantages of the method lie in the facts that only readily available chemicals are required, there is very little interference by. other substances, and the colour, which is reasonably stable, develops rapidly.

\section{REFERENCE}

Barkan and Walker (1940). J. biol. Chem., $135,37$. 